\title{
Action of two herbicides on the microbial activity of soil cultivated with common bean (Phaseolus vulgaris) in conventional-till and no-till systems
}

\author{
J B SANTOS*, A JAKELAITIS*, A A SILVA*, M D COSTA $\dagger$, A MANABE $\dagger \&$ M C S \\ SILVA $\dagger$ \\ *Departamento de Fitotecnia and $\dagger$ Departamento de Microbiologia, Universidade Federal de Viçosa (UFV), Brazil
}

Received 23 August 2005

Revised version accepted 22 February 2006

\section{Summary}

The effects of application of the herbicides fluazifop- $p$ butyl and fomesafen and the commercial mixture of these herbicides on the microbial activity of a soil, cultivated with common bean under no-till (NTS) and conventional-till (CTS) systems, were evaluated. Microbial respiration was monitored for 63 days after application (DAA) of the herbicides, and the following evaluated at 12 and 51 DAA: microbial biomass carbon (MBC), microbial quotient $(q \mathrm{MIC})$, metabolic quotient $\left(q \mathrm{CO}_{2}\right)$, percentage of bean root colonisation by mycorrhizal fungi and grain yield at the end of the cycle. A greater microbial respiratory rate was observed under NTS, with fluazifop-p-butyl providing the lowest respiration. At 12 DAA, MBC and $q$ MIC were most affected negatively by fomesafen and by the commercial mixture of the two herbicides. Mycorrhizal colonisation was affected by the herbicides only at 12 DAA under CTS; however, in both periods, the highest value was found under NTS. All the herbicides caused a decrease in the MBC and $q \mathrm{MIC}$ values at $51 \mathrm{DAA}$; the $q \mathrm{CO}_{2}$, which is related to the soil system stability, indicated a greater NTS balance over CTS. The herbicide fomesafen induced lower stability in the system. Lower grain yield was obtained without weed control (no herbicides) and with fomesafen-only treatments, which may be attributed to the high weed infestation in the experimental area.

Keywords: fluazifop-p-butyl, fomesafen, arbuscular mycorrhiza, no-till system, microbial quotient, metabolic quotient.

Santos JB, Jakelaitis A, Silva AA, Costa MD, Manabe A \& Silva MCS (2006) Action of two herbicides on the microbial activity of soil cultivated with common bean (Phaseolus vulgaris) in conventional-till and no-till systems. Weed Research 46, 284-289.

\section{Introduction}

Increased soil contamination by herbicides in intensive agricultural areas has attracted the interest of researchers in evaluating biological indicators of soil quality and has shown that soils can be affected. Understanding soil quality attributes allows progress towards sustainable soil management, as by monitoring the changes in soil quality one will be able to determine sets of sustainableoriented practices.

An accurate and consistent evaluation of soil quality may be accomplished by indicators such as microbial biomass (MB), responsible for the control of essential functions in the soil, such as decomposition and accumulation of organic matter or changes involving mineral nutrients or xenobiotic compounds. Microbial quotient ( $q \mathrm{MIC}$ ), which indicates the quality of organic matter by reflecting additions of it to the soil, estimates the efficiency of converting organic $\mathrm{C}$ into $\mathrm{MB}$ carbon or carbon losses in soil (Sparling, 1992); also, metabolic quotient $\left(q \mathrm{CO}_{2}\right)$, established through the relation between accumulated $\mathrm{CO}_{2}$ and total $\mathrm{MB}$ carbon, establishes that, as $\mathrm{MB}$ efficient use of the resources increases, less $\mathrm{C}$ is lost as $\mathrm{CO}_{2}$ through respiration, with the possibility of the latter being incorporated into the microbial tissues (Anderson \& Domsch, 1985). Thus,

Correspondence: Dr J Santos, Universidade Federal de Viçosa - Fitotecnia, Av. PH Rolfs s/n Campus - UFV Viçosa, Minas Gerais, 36570000 Brazil. Tel: + 55031 38992611; Fax: + 55031 38992611; E-mail: jbarbosasantos@yahoo .com.br 
lower $q \mathrm{CO}_{2}$ means higher $\mathrm{MB}$ stability, i.e. greater system stability. MB, which has a comparatively rapid formation and decomposition rate of 1 or 2 years (Jenkinson \& Ladd, 1981), may be proposed as a more sensitive measure of soil disturbances resulting from herbicide application, as its increase or decrease affects the total amount of organic matter in the soil.

Under a no-till system (NTS), a greater retention of organic compounds has been observed with the increased aggregation of particles (Beare et al., 1995); these protect the organic matter physically by forming barriers which isolate the microorganisms in the substrate, also affecting MB cycling (Elliott \& Coleman, 1988). Thus, the use of herbicides under this system will have a different impact from that observed under the conventional-till system (CTS).

Fomesafen is one of the most recommended herbicides for bean cultivation, controlling several dicotyledonous weeds. However, this herbicide is persistent in the soil, with a half-life from 2 to 6 months (Rodrigues \& Almeida, 2005). Normally, fomesafen is used in a mixture with fluazifop-p-butyl for the simultaneous control of dicotyledonous and grass weeds (Silva et al., 2003). Studies have shown that some herbicides affect MB negatively (Edwards, 1989; Wardle, 1994; Perschbacher et al., 1997; Kinney et al., 2005). However, these studies have not analysed climate conditions and tropical soils under NTS. This work evaluated the effects of the herbicides fluazifop- $p$-butyl and fomesafen applied alone or in a mixture (Robust ${ }^{\circledR}$ ) on the microbial activity of a soil in contrasted NTS and CTS of common bean (Phaseolus vulgaris L.) cultivation.

\section{Material and methods}

The experiment was carried out in the field and the analyses in the Laboratório de Herbicidas of the Universidade Federal de Viçosa (UFV), using samples of a Red-Yellow Argisol collected at the depth of $0-10 \mathrm{~cm}$ in areas cultivated with bean (cv. Ouro Vermelho) under NTS and CTS. In both areas, bean had been intercropped with maize (Zea mays L.) over 6 years. The chemical and textural characterisation of the soil, in each area, is shown in Table 1.

The experiment was arranged in split-split plots in a randomised block design, with four repetitions. The main plots constituted the planting systems (NTS and CTS) and the split plots constituted the treatments composed of the herbicides Fusilad $\AA$ (fluazifop-p-butyl - $187.5 \mathrm{~g}$ a.i. $\mathrm{ha}^{-1}$ ) and Flex ${ }^{\circledR}$ (fomesafen - $250 \mathrm{~g}$ a.i. $\mathrm{ha}^{-1}$ ) and their commercial mixture, Robust ${ }^{\circledR}$, at the doses of $140 \mathrm{~g}$ a.i. $\mathrm{ha}^{-1}$ of fluazifop-p-butyl $+175 \mathrm{~g}$ a.i. $\mathrm{ha}^{-1}$ of fomesafen, applied 30 days after bean sowing, plus a control without herbicide. Sub-plots
Table 1 Chemical and textural composition of a layer of $0-10 \mathrm{~cm}$ depth of clayey soil derived from no-till (NTS) and conventionaltill (CTS) systems used in the experiment

\begin{tabular}{|c|c|c|}
\hline & CTS & NTS \\
\hline \multicolumn{3}{|c|}{ Mineral fraction (\%) } \\
\hline Fine sand & 15 & 10 \\
\hline Coarse sand & 29 & 16 \\
\hline Silt & 11 & 19 \\
\hline Clay & 45 & 55 \\
\hline Texture & Clayey & Clayey \\
\hline \multicolumn{3}{|c|}{ Chemical analysis } \\
\hline \multicolumn{3}{|l|}{$\left(\mathrm{mg} \mathrm{dm} \mathrm{m}^{-3}\right)$} \\
\hline P & 13 & 14.1 \\
\hline $\begin{array}{c}\mathrm{K}+ \\
\left(\mathrm{cmol}_{\mathrm{C}} \mathrm{dm}^{-3}\right)\end{array}$ & 7.1 & 14.2 \\
\hline $\mathrm{H}+\mathrm{Al}$ & 4.62 & 4.29 \\
\hline $\mathrm{Al}^{3+}$ & 0.1 & 0.1 \\
\hline $\mathrm{Ca}^{2+}$ & 1.4 & 2 \\
\hline $\mathrm{Mg}^{2+}$ & 0.4 & 0.8 \\
\hline CEC (total) & 6.6 & 7.45 \\
\hline \multicolumn{3}{|l|}{ (\%) - } \\
\hline V & 30 & 42 \\
\hline $\mathrm{m}$ & 5 & 3 \\
\hline $\mathrm{OM}$ (dag $\mathrm{kg}^{-1}$ ) & 2.90 & 3.82 \\
\hline
\end{tabular}

Analyses carried out at the Soil Physical and Chemical Analysis Laboratories of the Department of Soils of the UFV. CEC, cation exchange capacity; OM, organic matter; V, base saturation; m, aluminium saturation.

were split into split-split plots with the evaluation timings.

Microbial respiration was estimated based on the amount of $\mathrm{CO}_{2}$ evolved from the samples of $100 \mathrm{~g}$ of soil, which were placed in flasks containing $100 \mathrm{~mL}$ of $\mathrm{NaOH}\left(0.25 \mathrm{~mol} \mathrm{~L}^{-1}\right)$ under a continuous air flow system (without $\mathrm{CO}_{2}$ and moisture), at 5, 12, 28, 51 and 63 days after application (DAA) of the herbicides. After the soil samples were sieved in a two-mesh sieve, air-dried and their water content determined, they were weighed and incubated in Erlenmeyer flasks at a water content of $80 \%$ of field capacity (approximately -0.5 bar or $-50 \mathrm{kPa}$ ). This was followed by indirect titration of sodium hydroxide with $\mathrm{HCl}\left(0.25 \mathrm{~mol} \mathrm{~L}^{-1}\right)$ so that the remaining $\mathrm{NaOH}$ that did not react with the evolved $\mathrm{CO}_{2}$ was quantified (Anderson, 1982).

In addition to microbial respiration, the following was determined at 12 and 51 DAA: (a) microbial biomass carbon (MBC) by the method described by Vance et al. (1987), replacing-chloroform (fumigation) by microwave oven (irradiation) (Islam \& Weil, 1998); (b) microbial quotient $(q \mathrm{MIC})$, through the relation between $\mathrm{MBC}$ and the organic C multiplied by 100; (c) metabolic quotient $\left(q \mathrm{CO}_{2}\right)$, through the relation between the accumulated $\mathrm{CO}_{2}\left(\mathrm{mg} 100 \mathrm{~g}^{-1}\right.$ soil $)$ and $\mathrm{MB}$ total $\mathrm{C}$ $\left(\mu \mathrm{g} \mathrm{g}^{-1}\right.$ soil); and (d) the percentage of bean roots 
colonised by mycorrhizal fungi was evaluated according to Giovannetti and Mosse (1980).

At 63 DAA, the bean was harvested and grain yield determined. The data were submitted to variance analysis by the $F$-test and the treatment averages for the traits evaluated were compared by the Tukey test at $5 \%$ probability. Regression curves were also fitted for evolution of the accumulated $\mathrm{CO}_{2}$ during the evaluation period.

\section{Results and discussion}

Regardless of the treatment applied, the $\mathrm{CO}_{2}$ evolution response was linear $(P<1 \%$ by $t$-test) throughout the sampled period (Fig. 1). Greater microbial respiration was observed under NTS, regardless of herbicide application. For the CTS, a greater uniformity was found between the herbicides for microbial activity response. However, greater differences were found between the NTS treatments, with the lowest and highest $\mathrm{CO}_{2}$ accumulation being observed for the soil samples treated, respectively, with fluazifop- $p$-butyl and fomesafen. A greater microbial respiration in the NTS soil compared with CTS soil confirms the findings of Aon et al. (2001), Balota et al. (2003) and FEBRAPDP (2005), and may be attributed to no soil turnover and the presence of a plant residue layer on the soil surface.

The responses of microbiota respiration to herbicide application are variable. Verifying the effect of herbicides on an aquatic microbial community, Perschbacher et al. (1997) observed that fomesafen and fluazifop$p$-butyl did not interfere in the soil respiration. However, other have confirmed that several herbicides, including glyphosate, atrazine and 2,4-D, affected soil quality status through indirect effect on respiration (Edwards, 1989; Aon et al., 2001).

Conventional-till system showed lower $\mathrm{MBC}$ in the soil samples without herbicide and with the commercial mixture at 12 DAA. Regardless of the herbicide treatment, MBC was higher in the NTS soil samples at 51 DAA (Table 2).

Regardless of the tillage system used, herbicide application reduced $\mathrm{MBC}$ in both periods evaluated. At 12 DAA, fomesafen and the commercial mixture elicited the greatest reductions in MBC in CTS soil. Under NTS, MB decrease was higher under application of the herbicide alone than with the mixture. At 51 DAA, a greater MBC reduction was provided by the commercial herbicide mixture (Table 2). Aon et al. (2001) verified that fungal and bacterial biomass treated with the herbicides atrazine, glyphosate, 2,4-D, 2,4-DB, EPTC and flumetsulan were less affected and more expressive under NTS than CTS.

Herbicide decreased $q \mathrm{MIC}$ similarly to $\mathrm{MB}$, with the commercial mixture having the greatest reductions at 51 DAA (Table 2). Wardle (1994) postulated that when the soil microflora is under stress, its carbon utilisation capacity is reduced; in this case, the relationship between $\mathrm{MBC}$ and organic $\mathrm{C}$ decreases, regulating $q \mathrm{MIC}$. Likewise, a change to a favourable condition may lead to a rapid $\mathrm{MB}$ increase, even if the organic $\mathrm{C}$ values remain the same.

A greater decrease of MBC and $q \mathrm{MIC}$ observed in the soil with the commercial mixture may be the result of the combined direct action of the herbicides on the soil microbiota, or indirectly via better control of the weeds competing against the bean plant. Decreased rhizosphere activity as a result of plant species control by the applied herbicides may be the major cause of MB reduction. Likewise, the rather expressive decrease of MBC under CTS may be explained by the greater exposure of the soil to the weather.

The direct influence of the herbicides on the microorganisms may be attributed to mechanism action. Fomesafen is an inhibitor of the enzyme protoporphyrinogen oxidase (protox), causing an accumulation of

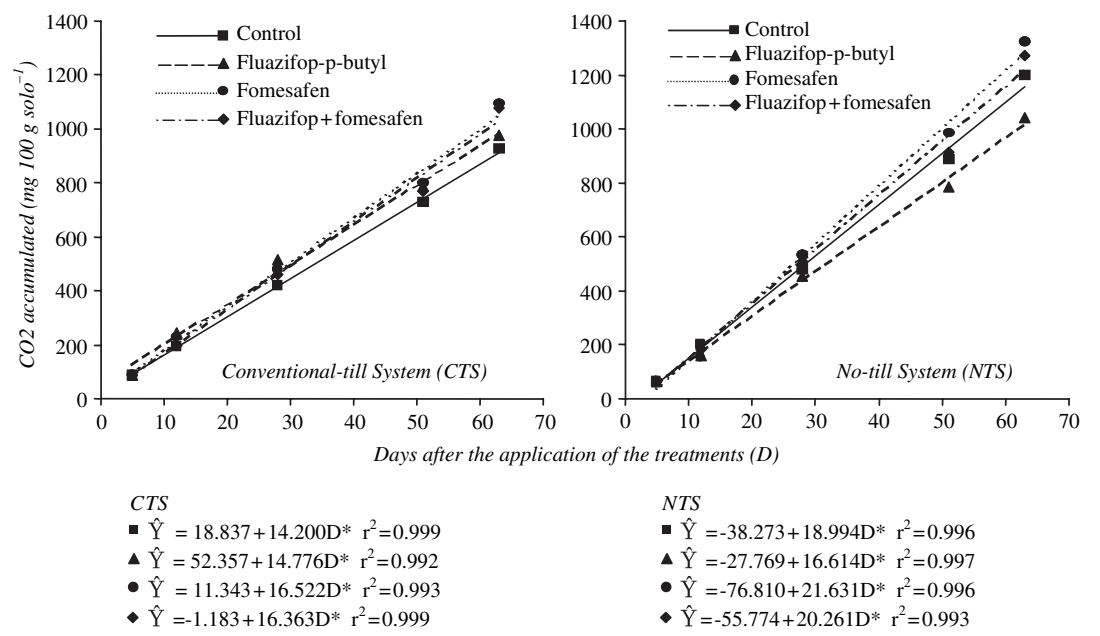

Fig. 1 Accumulated $\mathrm{CO}_{2}$ evolution over 63 days in soil derived from conventionaltill (CTS) and no-till (NTS) systems, following application of fluazifop- $p$-butyl (187.5 $\left.\mathrm{g} \mathrm{ha}^{-1}\right)$, fomesafen $\left(250 \mathrm{~g} \mathrm{ha}^{-1}\right)$ and the commercial mixture [fluazifop- $p$-butyl $\left(140 \mathrm{~g} \mathrm{ha}^{-1}\right)+$ fomesafen $\left.\left(175 \mathrm{~g} \mathrm{ha}^{-1}\right)\right]$. *Significant at $P<0.01$ by $t$-test. 
Table $2 \mathrm{C}$ values for microbial biomass carbon $(\mathrm{MBC})\left(\mu \mathrm{g} \mathrm{g} \mathrm{soil}^{-1}\right)$, microbial quotient $(q \mathrm{MIC})$ and metabolic quotient $\left(q \mathrm{CO}_{2}\right)$ in soil under conventional-till (CTS) and no-till (NTS) systems cultivated with bean applied the herbicides fluazifop-p-butyl $\left(187.5 \mathrm{~g} \mathrm{ha}^{-1}\right)$ and fomesafen $\left(250 \mathrm{~g} \mathrm{ha}^{-1}\right)$ and the commercial mixture Robust ${ }^{\circledR}$ [fluazifop- $p$-butyl $\left(140 \mathrm{~g} \mathrm{ha}^{-1}\right)+$ fomesafen $\left(175 \mathrm{~g} \mathrm{ha}^{-1}\right)$ ], evaluated at 12 and 51 days after application (DAA) of the treatments

\begin{tabular}{|c|c|c|c|c|c|c|}
\hline \multirow[b]{2}{*}{ Treatment } & \multicolumn{2}{|l|}{$\mathrm{MBC}$} & \multicolumn{2}{|l|}{$q \mathrm{MIC}$} & \multicolumn{2}{|l|}{$q \mathrm{CO}_{2}$} \\
\hline & CTS & NTS & CTS & NTS & CTS & NTS \\
\hline \multicolumn{7}{|l|}{$12 D A A$} \\
\hline Control & $388.23 \mathrm{aB}$ & $572.37 \mathrm{aA}$ & $2.308 \mathrm{aB}$ & $2.583 \mathrm{aA}$ & $0.059 \mathrm{aB}$ & $0.041 \mathrm{aA}$ \\
\hline Fluazifop-p-butyl & $281.08 \mathrm{bA}$ & $222.09 \mathrm{cA}$ & $1.667 \mathrm{aA}$ & $1.002 \mathrm{bA}$ & $0.078 \mathrm{bA}$ & $0.061 \mathrm{aA}$ \\
\hline Fomesafen & $166.56 \mathrm{cA}$ & $176.95 \mathrm{cA}$ & $0.991 \mathrm{bA}$ & $0.798 \mathrm{bA}$ & $0.114 \mathrm{cA}$ & $0.076 \mathrm{aA}$ \\
\hline Robust ${ }^{\circledR}$ & $209.19 \mathrm{cB}$ & $307.81 \mathrm{bA}$ & $1.242 \mathrm{bA}$ & $1.389 \mathrm{bA}$ & $0.082 \mathrm{bA}$ & $0.056 \mathrm{aA}$ \\
\hline \multicolumn{7}{|l|}{$51 D A A$} \\
\hline Control & $388.42 \mathrm{aB}$ & $464.21 \mathrm{aA}$ & $2.309 \mathrm{aB}$ & $2.095 \mathrm{aA}$ & $0.053 \mathrm{aB}$ & $0.028 \mathrm{aA}$ \\
\hline Fluazifop-p-butyl & $61.76 \mathrm{cB}$ & $286.86 \mathrm{bA}$ & $0.367 \mathrm{bB}$ & $1.295 \mathrm{bA}$ & $0.176 \mathrm{bB}$ & $0.041 \mathrm{bA}$ \\
\hline Fomesafen & $106.77 \mathrm{bB}$ & $242.62 \mathrm{bA}$ & $0.635 \mathrm{bB}$ & $1.095 \mathrm{bA}$ & $0.128 \mathrm{bB}$ & $0.072 \mathrm{bA}$ \\
\hline Robust® & $44.71 \mathrm{cB}$ & $93.52 \mathrm{cA}$ & $0.266 \mathrm{bA}$ & $0.422 \mathrm{cA}$ & $0.320 \mathrm{cB}$ & $0.200 \mathrm{cA}$ \\
\hline
\end{tabular}

Means of each characteristic (MBC, $q \mathrm{MIC}$ and $q \mathrm{CO}_{2}$ ) followed by the same lower-case letters in the column or upper-case letters on the line, for each evaluation time, do not differ by the Tukey test at $5 \%$ probability.

protoporphyrin in cells treated with this herbicide. This interacts with oxygen and leading to the production of reactive forms, and consequently, lipid peroxidation and cellular death (Warren \& Hess, 1995). Fluazifop-p-butyl is a potent inhibitor of the synthesis of acetyl-coenzyme A carboxylase (ACCase) (Hess, 1995), which is also present in the microbial metabolism. In addition, Procópio et al. (2004) showed that fomesafen is extremely toxic to the soybean nitrogen fixing bacteria Bradyrhizobium japonicum. A more representative estimate of any stress effects on the soil can be obtained by evaluation of the metabolic quotient $\left(q \mathrm{CO}_{2}\right)$, which relates the accumulated $\mathrm{CO}_{2}$ to total $\mathrm{MBC}$ (Anderson \& Domsch, 1985). This index establishes that, as the MB becomes more efficient in using the resources available, less $\mathrm{C}$ is lost as $\mathrm{CO}_{2}$ through respiration. In other words, lower $q \mathrm{CO}_{2}$ means higher $\mathrm{MB}$ stability and, consequently, lower organic matter in the soil. The NTS soil samples showed greater stability in the absence of the herbicides at $12 \mathrm{DAA}$, with fomesafen conferring the lowest stability to soil. The NTS samples did not show any $q \mathrm{CO}_{2}$ difference between the treatments during this period (Table 2).

At 51 DAA, $q \mathrm{CO}_{2}$ was lower under NTS for all treatments, indicating that this system was better balanced than the CTS (Table 2). Among the treatments, similarly to what occurred for NTS at 12 DAA, the absence of herbicides conferred lower $q \mathrm{CO}_{2}$, what shows that MB becomes less efficient in their presence, or these herbicides cause a disruption in carbon pools that stimulates respiration under both systems. In both systems, the herbicide mixture provided higher $q \mathrm{CO}_{2}$ (Table 2). Soils with high $q \mathrm{CO}_{2}$ are dominated by fastgrowing colonising organisms, reflecting a more unstable environment or further removed from its equilibrium state (Sakamoto \& Obo, 1994). This may be caused by the tillage system itself (comparing $\mathrm{CO}_{2}$ values between NTS and CTS), or by applying the tested herbicides (comparing with the control).

The colonisation of bean plant roots by mycorrhizal fungi was lower under CTS, regardless of herbicide application, this fact being attributed to a greater soil

Table 3 Colonisation of bean plant root (\%) evaluated at 12 and 51 days after application (DAA) of the herbicides fluazifop-p-butyl $\left(187.5 \mathrm{~g} \mathrm{ha}^{-1}\right)$, fomesafen $\left(250 \mathrm{~g} \mathrm{ha}^{-1}\right)$ and the commercial mixture Robust ${ }^{\circ}\left[\right.$ fluazifop-p-butyl $\left(140 \mathrm{~g} \mathrm{ha}^{-1}\right)+$ fomesafen $\left.\left(175 \mathrm{~g} \mathrm{ha}^{-1}\right)\right]$ and grain yield during harvest under conventional-till (CTS) and no-till (NTS) systems

\begin{tabular}{|c|c|c|c|c|c|c|}
\hline \multirow[b]{3}{*}{ Treatment } & \multicolumn{4}{|c|}{ Mycorrhizal colonisation (\%) } & & \\
\hline & \multicolumn{2}{|l|}{12 DAA } & \multicolumn{2}{|l|}{51 DAA } & \multicolumn{2}{|c|}{ Yield (kg ha $\left.{ }^{-1}\right)$} \\
\hline & CTS & NTS & CTS & NTS & CTS & NTS \\
\hline Control & $67.25 \mathrm{aB}$ & $71.75 \mathrm{aA}$ & $56.25 \mathrm{aB}$ & $72.00 \mathrm{aA}$ & 2058.33 bA & $2224.33 \mathrm{bA}$ \\
\hline Fluazifop-p-butyl & $31.25 \mathrm{cB}$ & $69.50 \mathrm{aA}$ & $59.50 \mathrm{aB}$ & 68.25 aA & $2550.00 \mathrm{aA}$ & $2413.33 \mathrm{abA}$ \\
\hline Fomesafen & $51.00 \mathrm{bB}$ & $67.25 \mathrm{aA}$ & $50.25 \mathrm{aB}$ & $65.75 \mathrm{aA}$ & $2216.67 \mathrm{bB}$ & $2466.67 \mathrm{abA}$ \\
\hline Robust® & $50.50 \mathrm{bB}$ & $62.50 \mathrm{aA}$ & $56.75 \mathrm{aA}$ & $62.75 \mathrm{aA}$ & $2741.66 \mathrm{aA}$ & $2600.00 \mathrm{aA}$ \\
\hline
\end{tabular}

Means followed by the same lower-case letters in the column or upper-case letters on the line, for roots colonised in each time or for grain yield, do not differ by the Tukey test at $5 \%$ probability. 
turnover under this system. Herbicide application reduced mycorrhizal colonisation at 12 DAA in the root samples collected under CTS. Mycorrhizal colonisation of control beans roots were $67 \%$, while beans from fomesafen-tested plots had a colonisation of $51 \%$ and $31 \%$ in fluazifop- $p$-butyl-treated beans (Table 3 ). Other works have also showed lower colonisation in crops due to herbicide application to the soil (Trappe et al., 1984; Paula \& Zambolim, 1994). Abd-Alla et al. (2000), investigating the effect of several pesticides on arbuscular mycorrhizal and nitrogen fixing symbioses in leguminous plants, reported that the herbicide paraquat significantly reduced mycorrhizal colonisation.

Overall, it can be stated that the application of different herbicides caused a negative effect on the soil microbiota. Such negative effects are lessened by the adoption of NTS, which, with no soil turnover and maintenance of straw on its surface, appears to provide a greater stability in the system. Among the herbicides studied, fomesafen may be considered the one causing the greatest negative impact on the soil microbial activity, also decreasing grain yield under CTS (Table 3$)$.

Thus, microbial activity indicators, such as $\mathrm{MBC}$, $q \mathrm{MIC}, q \mathrm{CO}_{2}$ and percentage of mycorrhizal fungus associated with the roots, may help to measure the effects of herbicide application under different tillage and crop rotation systems. Monitoring the variation of these indicators through time allows the planning and adoption of practices aimed at minimising the negative effects of crop production practices.

\section{Acknowledgements}

We are grateful to Conselho Nacional de Desenvolvimento Científico e Tecnológico (CNPq) and Coordenação de Aperfeiçoamento de Pessoal de Nivel Superior (CAPES) for the financial support.

\section{References}

Abd-Alla MH, Omar SA \& Karanxha S (2000) The impact of pesticides on arbuscular mycorrhizal and nitrogen-fixing symbioses in legumes. Applied Soil Ecology 14, 191-200.

ANDERSON JPE (1982) Soil respiration. In: Methods of Soil Analysis (eds AL Page, RH Miller \& DR Keeney), Vol. 1, Part 2, 831-871. American Society of Agronomy, Madison, WI, USA.

Anderson TH \& Domsch KH (1985) Determination of ecophysiological maintenance carbon requirements of soil microorganisms in a dormant state. Biology and Fertility of Soils 1, 81-89.

Aon MA, Sarena DE, Burgos JL \& Cortassa S (2001) (Micro) biological, chemical and physical properties of soils subjected to conventional or no-till management: an assessment of their quality status. Soil Tillage Research 60, 173-186.

Balota EL, Colozzi-Filho A, Andrade DS \& Dick RP (2003) Microbial biomass in soils under different tillage and crop rotation systems. Biology and Fertility of Soils 38, 15-20.

Beare MH, Coleman DC, Crossley DA Jr, Hendrix PF \& Odum EP (1995) A hierarchical approach to evaluating the significance of soil biodiversity to biogeochemical cycling. Plant Soil 170, 5-22.

EDwards CA (1989) Impact of herbicides on soil ecosystems. Critical Review Plant Science 8, 221-257.

Elliott ET \& Coleman DC (1988) Let the soil work for us. Ecological Bull 39, 23-32.

FEBRAPDP - Federação Brasileira de Plantio Direto na Palha (2005) http://www.febrapdp.org.br./area_PD_Brasil_ (12 March 2005).

Giovannetti M \& Mosse B (1980) An evaluation of techniques for measuring vesicular arbuscular mycorrhizal infection in roots. New Phytology 84, 489-500.

Hess FD (1995) Mode of action of lipid biosynthesis inhibitors (Graminicides - ACCase Inhibitors). In: Herbicide Action Course. Purdue University, West Lafayette, IN, USA.

IsLAm KR \& WeIL RR (1998) Microwave irradiation of soil for routine measurement of microbial biomass carbon. Biology and Fertility of Soils 27, 408-416.

JeNKINSON DS \& LADD JM (1981) Microbial biomass in soil: measurement and turnover. In: Soil Biochemistry (eds EA Paul \& JN Ladd), Vol. 1, 415-471. Marcel Dekker, New York, NY, USA.

KinNey CA, Mandernack KW \& Mosier AR (2005) Laboratory investigations into the effects of the pesticides mancozeb, chlorothalonil, and prosulfuron on nitrous oxide and nitric oxide production in fertilized soil. Soil Biology and Biochemistry 37, 837-850.

Paula TJ Jr \& Zambolim L (1994) Efeito de fungicidas e de herbicidas sobre a micorrização de Eucalyptus grandis por Glomus etunicatum. Fitopatologia Brasileira 19, 173-177.

Perschbacher PW, Stone N, Ludwig GM \& Guy CB (1997) Evaluation of effects of common aerially-applied soybean herbicides and propanil on the plankton communities of aquaculture ponds. Aquaculture 157, 117-122.

Procópio SO, Santos JB, Jacques RJS et al. (2004) Crescimento de estirpes de Bradyrhizobium sob influência dos herbicidas glyphosate potássico, fomesafen, imazethapyr e carfentrazone-ethyl. Revista Ceres 51, 179-188.

Rodrigues BN \& Almeida FS (eds) (2005) Uso de herbicidos. In: Guia de Herbicidas, 648. Londrina, Brazil.

SАкамото K \& Ово Y (1994) Effects of fungal to bacterial ratio on the relationship between $\mathrm{CO}_{2}$ evolution and total soil microbial biomass. Biology and Fertility of Soils 17, 39-44.

Silva AA, Ferreira FA \& Ferreira LR (2003) Controle de Plantas Daninhas. Associação Brasileira de Educação Agrícola Superior, módulo 3, 260. Brasilia, Brazil.

SPARLING GP (1992) Ratio of microbial biomass carbon to soil organic carbon as a sensitive indication of changes in soil organic matter. Australian Journal of Soil Research 30, 195207.

Trappe JM, Molina R \& Castellano M (1984) Reactions of mycorrhizal fungi and mycorrhiza formation to pesticides. Annual Review of Phytopathology 22, 331-359. 
Vance ED, Brookes PC \& Jenkinson DS (1987) An extraction method for measuring soil microbial biomass C. Soil Biology and Biochemistry 19, 703-707.

WARDLE DA (1994) Impact of disturbances on detritus foodwebs in agro-ecosystems of contrasting tillage and weed management practices. Advances in Ecological Research 26, 10-17.
WarRen GF \& Hess FD (1995) Mode of action of inhibitors of protoporphyrinogen oxidase (Diphenilethers and oxadiazon). In: Herbicide Action Course. Purdue University, West Lafayette, IN, USA. 